\title{
Wildlife Research and Monitoring in Nepal: An Overview
}

Buddi Sagar Poudel ${ }^{1}$

\begin{abstract}
Considerable research studies have been carried out in protected areas of Nepal over last three decades. Often, these studies are species oriented on selected endangered mammals and do not deliver conservation actions potentially to serve management needs. Comprehensive, multidisciplinary research approach and long term monitoring is scant at present and is of little conservation significance. Research policies, guidelines, prioritization and evaluation criteria are important facets for sound protected area management. Persistent concerted efforts are needed to make research and monitoring as an integral part of protected area management. This paper reviews present state of wildlife research in Nepal's protected areas. The conservation laws and regulation related to research studies are dealt in brief. Also, the endangered species monitoring exercises are discussed and finally, this paper offers some prospective options to make the protected areas as learning centers from conservation standpoint and recommends documentation and dissemination of researched information.
\end{abstract}

Key Words: Protected area, Research \& monitoring, Rhino, Tiger, Gharial, Gaur, Swamp deer.

\section{Introduction}

Protected area research has had a long history in Nepal. Over the last three decades or so a plenty of researches have been done in protected areas of Nepal. Nepal's protected areas (PAs) are known as extensively studied areas. Despite the vast and diverse repository of biological diversity in protected areas, its flora and fauna have been inadequately explored and even if the studies were undertaken, the existing information are scattered.

Research refers to search for new knowledge. Good research is systematic, logical, empirical and replicable. Research enhances benchmark knowledge and improves decision making. Research helps in identification of monitoring indicators. Thus, research and monitoring are two related but different and equally important parallel activities. Monitoring is an exercise in which a set of qualitative or quantitative observations are made, usually by means of a standardized procedure within a restricted period of time, but without any preconception of what the results ought to be.

The goal of managing wildlife populations are frequently expressed in terms of population size. When dealing with endangered species the managers are trying to rapidly increase population size. Population size is thus the currency by which the success of species management is ultimately judged. Population size has the central role in wildlife management. However, a

\footnotetext{
${ }^{1}$ Department of National Parks and Wildlife Conservation, Babarmahal, Kathmandu, Nepal, spoudel@dnpwc.gov.np
} 
single estimate of population size at one point in time and space is usually of limited value. Instead, regular estimates of population size would help place a particular estimate in proper perspective for the species long term survival. Such regular estimates allows inferences about population status relative to previous years, gives trend which reflects direction and magnitude of change over a period of time. The reasons for species monitoring are legion but can be categorized into; 1) evaluating the effectiveness of conservation plans, policies and management interventions, 2) assessing the attainment of desired condition for management purposes, and 3 ) detecting incipient change (early warning). As a consequence, wildlife research and monitoring cannot be overshadowed by any other activities.

In this paper, information is furnished on present state of wildlife research and monitoring in Nepal's PAs. It also highlights endangered wildlife monitoring exercises carried out by DNPWC in the year 2007 and 2008. The annual reports of DNPWC from F/Y 2050/051 to date were cursorily examined. Similarly, the regular publications of DNPWC, especially the Wildlife Newsletter (in English) and Samrakshan Samachar (in Nepali) published in the year 2007 and 2008 were traced for population monitoring. It also reflects the author's accumulated experience on the subject as being involved in monitoring exercises.

\section{Current Legal Instruments: Are they conducive?}

National Parks and Wildlife Conservation Act 2029 allows the collection of specimen for scientific research and its Regulation 2030 specifically catalogued the fees to be levied for specimen collection for said purpose. Chitwan National Park Regulation 2030, Wildlife Reserve Regulation 2034, Himalayan National Park Regulation 2036, Bardia National Park Regulation 2053 states that the research work can be carried out after getting pre-approval from Government of Nepal. In such a case, the research report accrued thereof should be submitted to the Government.

Khaptad National Park Regulation 2044, Buffer Zone management Regulation 2052 and Kanchenjungha Conservation Area Management Regulation 2064 highlighted that any person desired to do any work, relating to research, may conduct after receiving pre-approval of the Department and a copy of his research report should be submitted to the Department. Rule 36 (1) of Buffer Zone management Regulation 1996 further provisioned that the Department may give permission to a foreigner or institutions desirous to carry out research work in buffer zone after charging prescribed fees. Similarly, Conservation Area Management Regulation 2053 said that the pre-approval from Chief of conservation area is must to carry out any research work in area.

However, Department is enabling Nepalese researchers into PAs research and studies. Department, based on full fledged proposal, application and recommendation from concerned institution or supervisor is granting permission to carry out their research study. In case of foreigners, it will forward the application to the Ministry of Forests and Soil Conservation and decisions will be made accordingly. The research permission is issued stating that the research report has to be compulsorily sent to the respective protected area office and DNPWC but the 
researchers rarely submits. Sometimes, the terms and conditions are set forth by the Department. This shows that there is a need to improve mechanism for requisite permissions.

\section{The Present State of Research}

Protected area research has traveled a relatively long way since its birth. Research permission taken from DNPWC in last few years provided ample evidences to this. However, there is a great need for basic ecological knowledge (Burkey, 1997) and in the absence of a clear picture of the ecological condition, substantial gap still exists in Nepal. Due to lack of complete inventory and continuous investigation, the protected areas have tremendous potentiality of research to grasp (Kumaran, 2002). A list of the number of researches/studies from protected areas of Nepal during the F/Y 2050/051 to 2063/064 is presented in table 1 .

The exact number of research in the year 2051/

Table 1: Research studies in PAs of Nepal

052 could not be traced. Though, there is a abrupt increase in the number of researches in 2063/ 064 and 2064/065, in many incidences in-depth investigations are overlooked. It is unfortunate that the studies, with few exceptions, are not published. Very few of published papers were subjected to peer review. The research reports though made compulsory to send to the respective park office and to DNPWC, are rarely available. Research carried out in 2063/064 and 2064/065 contributed almost $50 \%$ to the total 572 researches permitted during last 15 years. The large number of researches in 2063/064 and 2064/ 065 is merely due to improved security situation after extensive peace accord between the Government of Nepal and the CPN Maoist and subsequent awareness among researchers to study in protected areas, may perhaps be due to availability of research fund from various conservation institutions in Nepal and abroad. Mostly the existing researches are species oriented research on selected endangered mammals. However, the focused studies on lesser known species are rather minimal.

\begin{tabular}{|l|l|}
\hline \multicolumn{1}{|c|}{$F / Y$} & \multicolumn{1}{c|}{ Number } \\
\hline $2064 / 065$ & 147 \\
\hline $2063 / 064$ & 130 \\
\hline $2062 / 063$ & 26 \\
\hline $2061 / 062$ & 41 \\
\hline $2060 / 061$ & 26 \\
\hline $2059 / 060$ & 23 \\
\hline $2058 / 059$ & 21 \\
\hline $2057 / 058$ & 26 \\
\hline $2056 / 057$ & 29 \\
\hline $2055 / 056$ & 31 \\
\hline $2054 / 055$ & 24 \\
\hline $2053 / 054$ & 22 \\
\hline $2052 / 053$ & 17 \\
\hline $2051 / 052$ & NA \\
\hline $2050 / 051$ & 9 \\
\hline Total & 572 \\
\hline
\end{tabular}

Source: Annual Reports, DNPWC

Sporadic studies on people-wildlife interface, resource mapping and socio-economic research also exists. Most of the studies are conducted in accessible protected areas i.e., Shivapuri, Chitwan, Langtang and Bardia National Parks. The majority of the past research studies have been of short duration. Often, they do not deliver conservation actions. Moreover, most of the research studies reflect the fact that the study remained largely as pursuit of students of various college and university for their academic purpose. 


\section{Wildlife Monitoring}

Conservation and management of species require basic information on population dynamics and distribution at different time scale. Policy makers, planners, wildlife managers and conservation organizations need clear and reliable information on animal population. Although it is desirable to carry out population count every year, it is not possible to do this for various reasons given the meager resources prevail.

DNPWC is a conservation committed governmental organization of Nepal with a network of 9 national parks, 3 wildlife reserves, 3 conservation areas, 1 hunting reserve and 11 buffer zone and have over 25 years of conservation experience in wildlife and protected area management in Nepal. It's purpose is to conserve, protect and restore the rich and varied fauna, flora and landscape of the mountainous country of Nepal. This is achieved through knowledge-based management and informed-decision processes.

Since last few years, DNPWC in collaboration with other conservation partners implemented wildlife monitoring exercises. This paper does not describe all; rather the endangered wildlife monitoring exercises carried out in 2007 and 2008 are explained here under in brief.

Table 2: Wildlife monitoring in PAs of Nepal

\begin{tabular}{|c|c|c|c|c|c|}
\hline Species & Year & Place & Methods & Results & Collaboration \\
\hline Rhino count & 2008 & $\begin{array}{l}\text { Chitwan and } \\
\text { Bardia NP }\end{array}$ & $\begin{array}{l}\text { Total direct } \\
\text { count }\end{array}$ & 430 & $\begin{array}{l}\text { DNPWC/CNP/BNP/NA/ } \\
\text { WWF N epa1/N TNC/ } \\
\text { ZSL/D arwin Initiative }\end{array}$ \\
\hline Gaur count & 2008 & Parsa WR & $\begin{array}{l}\text { Total direct } \\
\text { count }\end{array}$ & 37 & $\begin{array}{l}\text { DNPWC/PWR/NA/WW } \\
\text { F Nepal-TAL }\end{array}$ \\
\hline Tiger monitoring & 2008 & $\begin{array}{l}\text { Suklaphanta } \\
\text { WR }\end{array}$ & $\begin{array}{l}\text { Photographic- } \\
\text { capture- } \\
\text { recapture } \\
\text { sampling method }\end{array}$ & $7(6-14)$ & $\begin{array}{l}\text { DNPWC/SWR/WWF } \\
\text { N epal-TAL/NTNC-SCP }\end{array}$ \\
\hline $\begin{array}{l}\text { Gharial } \\
\text { monitoring }\end{array}$ & 2008 & $\begin{array}{l}\text { Koshi, } \\
\text { Narayari, } \\
\text { Rapti, } \\
\text { Babai, } \\
\text { Karnali } \\
\text { rivers }\end{array}$ & $\begin{array}{l}\text { Total direct } \\
\text { count }\end{array}$ & 81 & DNPWC/WWF N epal \\
\hline $\begin{array}{l}\text { Swamp deer } \\
\text { count }\end{array}$ & 2007 & $\begin{array}{l}\text { Suklaphanta } \\
\text { WR }\end{array}$ & $\begin{array}{l}\text { Total direct } \\
\text { count }\end{array}$ & 1674 & $\begin{array}{l}\text { SWRWWF Nepal- } \\
\text { TAL/N TNC-SCP }\end{array}$ \\
\hline
\end{tabular}

\section{Rhino count 2008 in Nepal}

As in the past, DNPWC in collaboration with NTNC and WWF Nepal conducted Rhino Count 2008 in Chitwan and Bardia National Park (and the potential areas surrounding these Parks) from the $1^{\text {st }}$ to $23^{\text {rd }}$ March, 2008 with an objective of ascertaining the current population 
status including number, distribution and population dynamics of rhinoceros in Nepal that can serve as the basis for future management decisions and to objectively evaluate the success or failure of past management interventions, so as to react adaptively and solve problems.

Rhino Count 2008 was started from $1^{\text {st }}$ March, 2008 in Bardia National Park (BNP) and completed on $8^{\text {th }}$ March, 2008 where as the count was held in Chitwan National Park (CNP) between $8^{\text {th }}$ and $23^{\text {rd }}$ March, 2008. Ten elephants with 50 technicians and logistic personnel in BNP and 28-42 elephants with about 200 technicians and logistic personnel were involved in count.

The rhino population was based on direct count of rhino. The rhino distribution area was divided into several blocks based on physical demarcation, prior experience, field monitoring knowledge and logistics. Each elephant observer team was provided with the Rhino sighting recording forms, invasive species recording forms, GPS receiver with logged transects, pair of binoculars, digital camera and communication (Walkie-talkie) sets. All the observers were trained in the use of the equipments prior to the census.

Rhino Count 2008 recorded a total of 408 rhinoceros in and around Chitwan National Park and 22 rhinoceros in Karnali flood plain area of Bardia National Park. According to the monitoring report of Suklaphanta Wildlife Reserve, there are 5 rhinos. Altogether, there are 435 greater one-horned rhinoceros in Nepal in March 2008 (Chaitra, 2064). The details are presented in following table.

Table 3: Rhino population in Nepal (DNPWC, 2008)

\begin{tabular}{|c|c|c|c|c|c|c|c|c|c|c|}
\hline \multirow{2}{*}{$P A$} & \multicolumn{3}{|c|}{ Alnet } & \multicolumn{3}{|c|}{ Sub-ahut } & \multicolumn{3}{|c|}{ Cayf } & \multirow{2}{*}{ Total } \\
\hline & Male & Female & Unkonown & Male & Female & |Unknown & Male & Fenale & |Unknown & \\
\hline Chitwon NP & 85 & 113 & 79 & 8 & 9 & 34 & 7 & 8 & 65 & 408 \\
\hline Bardia NP & 3 & 6 & 6 & 1 & 0 & 0 & 1 & 0 & 5 & 22 \\
\hline $\begin{array}{l}\text { Suldaphanta } \\
W R\end{array}$ & 1 & 2 & 0 & 0 & 0 & 0 & 0 & 0 & 2 & 5 \\
\hline Total & 89 & 121 & 85 & 9 & 9 & 34 & 8 & 8 & 72 & 435 \\
\hline
\end{tabular}

The Greater One-Horned Rhinoceros is listed as protected animal in Nepal under National Parks and Wildlife Conservation Act 2029, as endangered in IUCN Red Data Book, and is listed in Appendix I of CITES.

\section{Tiger monitoring 2008 in suklaphanta wildlife reserve}

Suklaphanta Wildlife Reserve (SWR) is a home to a wide range of vertebrates. SWR is a hub for flagship species among the other protected areas system in low land area of Nepal. SWR lies in Tiger Conservation Unit 43, which is priority area from tiger conservation point of view. The tiger monitoring was done between January and April, 2008 with the objective of assessing the abundance of tigers in core area of Suklaphanta Wildlife Reserve by using camera trap survey. Capture and Recapture Model has been used for the estimation purpose. Due to large 
sampling area and limited number of camera traps, sampling area was divided into eight sampling blocks and camera traps were rotated within the blocks. At one time, 12-13 camera sets were deployed and each camera set was kept for $14 \mathrm{hrs}$ at each trapping station. The camera units were used continuously at each station for 10 consecutive days in each of the eight blocks (Tiger Task Force Team/SWR, 2008).

Based on tiger monitoring, a capture-recapture model that permits capture probabilities to vary among individual tigers $\left(\mathrm{M}_{\mathrm{h}}\right)$ estimates tiger abundance of 7 with confidence interval 6-14 $(P=0.95)$. Comparison of population estimates of $2004 / 05$ with $2005 / 06$ and $2007 / 08$ shows considerable decrease in population (ibid).

Table 4: Tiger population estimates in SWR (Tiger Task Force Team/SWR, 2008)

\begin{tabular}{|c|c|c|c|c|c|c|}
\hline Season & $\begin{array}{c}\text { Estimated } \\
\text { sample } \\
\text { area }\left(\mathrm{km}^{2}\right)\end{array}$ & $\begin{array}{c}\text { Individual } \\
\text { Tiger } \\
\text { Identified }\end{array}$ & $\begin{array}{c}\text { Extimited } \\
\text { Population } \\
\text { (SEM) }\end{array}$ & $\begin{array}{c}\text { Confidenc } \\
\text { e Intenal } \\
(P=0.05)\end{array}$ & $\begin{array}{c}\text { Caphore } \\
\text { Probability }\end{array}$ & $\begin{array}{c}\text { Denxity } \\
\text { Extimntes (no of } \\
\text { tigers } / \mathrm{L} 00 \mathrm{~km} \text { ) }\end{array}$ \\
\hline $2004 / 05$ & 164.7 & 15 & $\begin{array}{c}27 \\
(7.0743)\end{array}$ & $20-50$ & 0.1074 & 16.39 \\
\hline $2005 / 06$ & 182.8 & 9 & $10(1.51)$ & $10-17$ & 0.1828 & 5.47 \\
\hline $2007 / 08$ & 240.6 & 5 & $7(1.9290)$ & $6-14$ & 0.1286 & 2.91 \\
\hline
\end{tabular}

\section{Gaur count 2008 in parsa wildlife reserve}

With the objectives of ascertaining the current status and distribution of Gaur (Bos gaurus) in Parsa Wildlife Reserve (PWR), a census was carried out between $23^{\text {rd }}$ and $27^{\text {th }}$ May, 2008 by the PWR in coordination with the DNPWC, WWF Nepal, Terai Arc Landscape Program, Naya Ranbhim Gulma of Nepal Army and Buffer Zone Management Committee. One day orientation workshop was organized at Adhabhar for observers prior to actual execution of the census. For the census, the probable Gaur area of the PWR was divided into 4 blocks. Sex, age, location, group size, habitat, time were recorded. Nine elephants, twelve recorders and 30 logistic personnel participated in the count. Global Positioning System (GPS), digital camera, binocular, maps, communication sets were used for the census purpose. Altogether 247.5 elephants working hours were spent for the actual count. The area covered during census includes Chiple Khola / Vedaha Khola in the east, through Mahadev Khola, Jamuniya Khola and Bhata Khola to Rambhori Khola/ Ghodemasan Khola in the west. The area north of Adhabhar-Charbhaiya fireline upto foothills of Churiya was covered during the census. Effectively sampled area is ca. 170 square kilometer (PWR, 2008).

The census recorded 37 Gaurs. Of them, 28 were direct sightings and 9 were indirect counts. Of 37, 8 were males, 11 females and 18 unknown. According to age category, 17 were adults, 2 sub-adults, 9 calf and 9 unknown (PWR, 2008). Most of the sightings were made in Sal forests and riverine forests. There were few past opportunistic sightings of Gaur from western sector of PWR (ibid). Therefore, the data on Gaur was collected during the course of preybase monitoring and found 23 additional individuals of Gaur. In Nepal, the Gaur is listed as 
protected animal under National Parks and Wildlife Conservation Act 2029, as vulnerable in IUCN Red Data Book, and is listed in Appendix I of CITES.

\section{Gharial crocodile monitoring 2008 in Nepal}

A study on population status and distribution of Gharial (Gavialis gangetics) in Nepal was commissioned by Department of National Parks and Wildlife Conservation and WWF Nepal in January-February 2008 aiming at updating the existing status and distribution pattern of Gharial and also assessing the threats in Gharial conservation in Nepal. Empirical data were collected from direct count using opportunistic search method and questionnaire survey from Koshi River of eastern Nepal, Narayani and Rapti of central Nepal and Karnali and Babai rivers of western Nepal.

The census estimated a total of 81 Gharial in Nepal (Khadka et.al., 2008). Out of total Gharial recorded during the census, 70 were directly recorded and 11 were based on indirect counts (Table-5). Census conducted in Koshi river could not detected any Gharial and their signs.

Table 5: Gharial crocodile population in 2008 (Khadka et.al., 2008)

\begin{tabular}{|c|c|c|c|c|c|c|}
\hline $\begin{array}{l}\text { River } \\
\text { system }\end{array}$ & \multirow{2}{*}{$\begin{array}{l}\text { Surveyed river } \\
\text { section (km) }\end{array}$} & \multicolumn{3}{|c|}{ Direct sightings } & \multirow{2}{*}{$\begin{array}{r}\text { Indirect } \\
\text { recorls }\end{array}$} & \multirow{2}{*}{$\begin{array}{c}\text { Total } \\
\text { individual } \\
0\end{array}$} \\
\hline Koshi & & $\begin{array}{l}\text { Male } \\
0\end{array}$ & $\begin{array}{l}\text { Female } \\
0\end{array}$ & $\begin{array}{l}\text { Unknown } \\
0\end{array}$ & & \\
\hline Noroyoni & 102.5 & 2 & 27 & 5 & 7 & 47 \\
\hline Rapti & 50.90 & 4 & 8 & 12 & 0 & 24 \\
\hline Kanali & 53.76 & 0 & 0 & 2 & 4 & 6 \\
\hline Babai & 39.52 & $\begin{array}{l}1 \\
7\end{array}$ & $\begin{array}{l}1 \\
36\end{array}$ & $\begin{array}{l}8 \\
27\end{array}$ & $\begin{array}{l}0 \\
77\end{array}$ & 70 \\
\hline
\end{tabular}

Nepal started captive breeding program of Gharial in 1978 and there are 2 Gharial breeding centres (Kasara, Chitwan and Thakurdwara, Bardia). Since 1981 to 2007, 691 Gharials have been released in different river systems. Out of 691, 339 were released in Narayani, 99 in Rapti, 85 in Koshi, 50 in Babai, 35 in Kali Gandaki and 23 in Karnali river. In Nepal, the Gharial is listed as protected animal under National Parks and Wildlife Conservation Act 2029, as critically endangered in IUCN Red Data Book, and is listed in Appendix I of CITES. Gharial is the only surviving member of Gavialidae family. It mostly inhabits large bodied, deep, fast flowing rivers in the plain.

\section{Swamp deer count 2007 in suklaphanta wildlife reserve}

Established in 1976, the famed Suklaphanta Wildlife Reserve (SWR) is a home to the wide range of vertebrates. SWR was set up exclusively for Swamp deer (cervus duvauceli), which is considered to be first organized approach to managing Swamp deer in Nepal (Poudel, 2007). As per Swamp deer count carried out at the reserve by Suklaphanta Wildlife Reserve in partnership with Terai Arc Landscape Program and Suklaphanta Conservation Program, 
the reserve is home to 1674 Swamp deer (world's largest herd of Swamp deer). The number of Swamp deer was found slightly higher in comparison to previous year's count (2006) which recorded a total of 1639 (DNPWC, 2007). Of the total Swamp deer counted in 2007, 1552 were found in Suklaphanta grassland and rest was recorded from other grasslands of the reserves. The population count of swamp deer was carried out between the 9th and the 11th April, 2007 (ibid). The count was based on direct count of animals. Swamp deer is a protected species of Nepal and listed in Appendix 1 of CITES.

\section{Discussion}

Nature has offered vast biodiversity to Nepal and there are several opportunities to establish Nepal's protected areas as learning center. However, the research activities by park and reserve office are falling far behind. The protected area manager is mostly engaged in coordination sparing little time for the park activities. The working areas and time of the existing staffs have shifted from core areas to buffer zone. As a result, core area management is getting weaker. Research and monitoring has not been seriously taken as a result, information even on the protected species and biological profile of the protected area is not complete. So, there is a need of a trained man power for scientific research and monitoring. This should be made indispensable part of protected area management system.

Obviously, patrolling is a basic and the most important function of protected areas. In spite of patrolling, research and monitoring has remained a low priority activity in most of the protected areas. A simple monitoring process consists of recording wildlife encounters by the staff while on routine patrols, in a standardized format should be practiced in protected areas. The data so collected over a period of time can provide insights into the population dynamics and distribution of most species. There is a need to have periodic (perhaps yearly) monitoring exercises. This could be done by using park staffs, elephants and resources, including the local stakeholders into monitoring process and making them partners and owners.

The culture of collaboration is much appreciating in protected area management. There are plenty of examples of collaboration in wildlife monitoring between the Department and conservation partners, particularly WWF Nepal and NTNC. Table 2 illustrates the collaboration in monitoring programs. This kind of collaboration is essential in research domain too. However, the projects and partner organizations, in many cases, are outsourcing research activities without involving department in designing, reviewing and granting research fund.

Despite having good management plan of protected areas and species conservation action plan of endangered species, the full implementation is lagging behind. The management plan should be made very pragmatic and simple. In fact, the Department officials, respective PAs Chief/Warden, Rangers, technicians and other wardens who have prior knowledge of the area should prepare the management plan and the research, monitoring and training needs has to be identified figuratively at the management plan. Once the research agendas are identified, the department could circulate the priority research studies to concerned institutions and researchers. 
Capacity building opportunities are not sufficient. As a result, the front line staffs are unequipped with new methods and techniques of wildlife research and monitoring and other allied fields. Use of Geographic Information System and remotely sensed data (satellite imageries) are useful for wildlife management and habitat mapping. This need to be aggressively developed with up-to-date spatial data for making informed management decisions.

The comprehensive research approach to serve the conservation needs and long term monitoring plan are lacking. The department has to place emphasis on collection, documentation and dissemination of information on national park management to a wider audience. As an exemplary step, HKKH Partnership Project has prepared a list of 1129 published and grey literatures related to Sagarmatha National Park (ICIMOD, 2008). Similarly, the bibliography of the past research studies should be prepared for all protected areas. Moreover, there should be research and monitoring officer posts in each protected areas. There is an urgent need to update the protected species list of NPWC Act 2029 but no such scientific information are sufficiently available for this purpose.

The studies like morphometric measurements are possible from dead body, which can be initiated in each park. The department should promote non-invasive sampling techniques (Pradhan, 2007) which cause minimum disturbances to the animals. Except tiger ecology project, there is not a long term research in Nepal's protected areas. Well planned, comprehensive, multidisciplinary and detailed experimental researches are needed to meet conservation needs. The relevance of research and monitoring as an integral part of PA management cannot be overemphasized. It has been well illustrated that the research and monitoring program should be devised by the Department and protected areas under it.

\section{Conclusions and Recommendations}

First, the values of research and monitoring in conservation planning must be acknowledged as an important aspect of protected area management. Long term monitoring of wildlife needs to focus on two aspects. One is to internalize the monitoring as part of the protected area program rather than the central level program, and the other is to publish the results. There is very high possibility of using GPS, GIS and Remote sensing methods successfully to the population survey and habitat mapping. Documentation and dissemination of researched information is urgently required.

DNPWC must proactively work towards promoting high quality scientific research work that is useful in addressing important management questions. It is felt that to conserve the protected area effectively, it needs action oriented research/study, which needs to be integrated with the conservation and management of biological resources. Information on population estimation is imperative to design and implement meaningful conservation measures. There is a need for shift in research paradigm to meet conservation needs.

The following actions have been recommended to bridge the above-mentioned gap in research/ monitoring and sound protected area management. 
1. The research-management gap needs to be acknowledged.

2. Research policies, guidelines, prioritizations and evaluation criteria should be prepared.

3. Research and monitoring need to be incorporated within broader protected are management system.

4. At least $10 \%$ of park budget should be allocated for research and monitoring.

5. Research, monitoring and training cell should be based in DNPWC and in each protected area.

6. Protected area personnel should be trained and involved in wildlife research and monitoring.

7. Formal institutional linkages need to be expanded with universities, research institutions, NGOs and sponsors.

8. Mechanisms for requisite permission need to be improved.

9. User-friendly monitoring protocols for protected, endangered and endemic species should be developed.

10. The DNPWC Management Information System (MIS) formats need to be practised fully in wildlife research and monitoring.

11. Researched information should be documented and disseminated to related stakeholders.

12. Annual research seminar seems appropriate to source research questions and share research findings.

\section{References:}

Burkey, TV. 1997. Ecological principles for Natural Habitats Management. Working paper 1997/7. Centre for Development and the Environment. University of Oslo, Norway

DNPWC, 2007. Increasing Swamp Deer Population in Suklaphanta Wildlife Reserve. Wildlife Nepal Newsletter, Year 17, No. 12. Department of National Parks and Wildlife Conservation, Kathmandu, Nepal

DNPWC, 2008. Rhino Count 2008 Concluded. Wildlife Nepal Newsletter, Year 18, No. 10. Department of National Parks and Wildlife Conservation, Kathmandu, Nepal

DNPWC, v.d. Annual Reports; 2050/051, 2051/052, 2052/053, 2053/054, 2054/055, 2055/ 056, 2056/057, 2057/058, 2058/059, 2059/060, 2060/061, 2061/062, 2062/063, 2063/ 064, 2064/065. Department of National Parks and Wildlife Conservation, Kathmandu, Nepal

ICIMOD, 2008. Land covers dynamics in Sagarmatha National Park. International Centre for Integrated Mountain Development, Kathmandu, Nepal 
Khadka, M, Thapaliya, BP and Kafley, H. 2008. Gharial Crocodile Monitoring in Nepal. A Report Submitted to WWF Nepal and Department of National Parks and Wildlife Conservation, Kathmandu, Nepal

Kumaran, PL. 2002. Marine mammal research in India- a review and critique of the methods. Current Science, 83 (10): 1210-1220

Poudel, BS. 2007. Analysis of use cases, decision process and information flow in Protected Area Management in Nepal. A Report submitted to ICIMOD. May 2007

Poudel, BS. 2007. Thirty years of managing Suklaphanta, the Swamp Deer and the Tiger: Issues and Strategies. The Initiation Vol. 1, No. 1. SUFFREC, Kathmandu, Nepal

Pradhan, NMB. 2007. An ecological study of a re-colonizing population of Asian elephants (Elephas maximus) in lowland Nepal. Doctor Scientiarum Thesis. Department of Ecology and Natural Resource Management, Norwegian University of Life Sciences, Norway

PWR. 2008. Gaur Bos gaurus Count in Parsa Wildlife Reserve. A Report submitted to Department of National Parks and Wildlife Conservation, Kathmandu, Nepal

Tiger Task Force Team/SWR. 2008. Tiger Monitoring in Suklaphanta Wildlife Reserve. Tiger Task Force Team/Suklaphanta Wildlife Reserve. A Wildlife Monitoring Report submitted to Department of National Parks and Wildlife Conservation, Kathmandu, Nepal
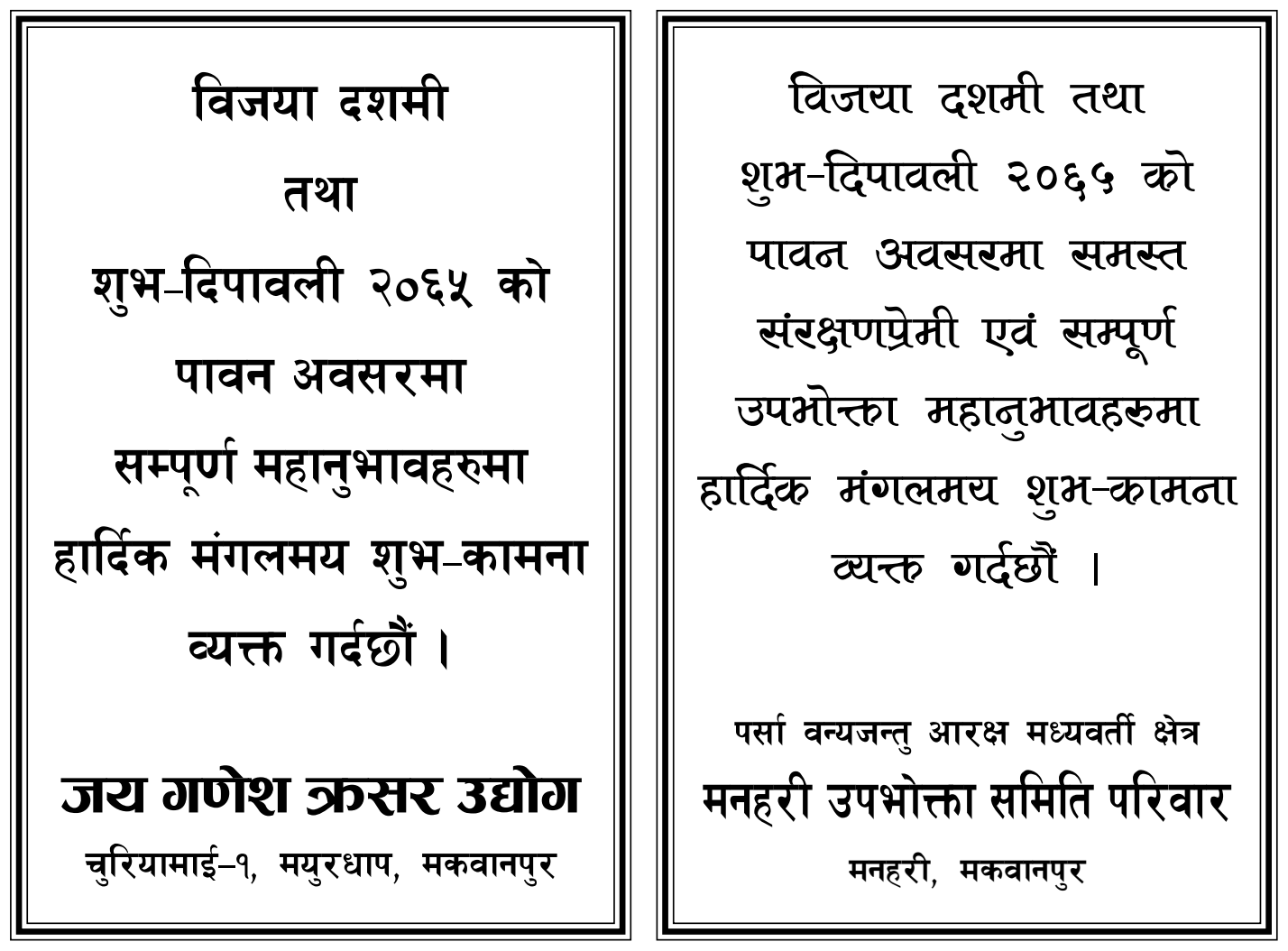